\title{
Interiorização de novos campi de Institutos Federais: análise ergonômica do ambiente construído de uma biblioteca no interior do nordeste brasileiro
}

\author{
Interiorization of new Federal Institutes campuses: ergonomic \\ analysis of the built environment of a library in the Brazilian \\ Northeast region
}

RAPHAELA BANKS

Mestra, UFPE, raphabanks@gmail.com

ALINE SILVA

Graduanda, UFPE, alinekasi@gmail.com

GAEL ARAÚJO

Graduando, UFPE, gael.arj7@gmail.com

BRUNO BARROS

Mestre, UFPE, barros_bruno@hotmail.com

\section{RESUMO}

Nas últimas duas décadas Universidades, Institutos Federais e instituições privadas intensificaram o processo de interiorização de seus campi (até então predominantemente situados em capitais), o que levou a uma acelerada construção de novas edificações. Dada a velocidade do fenômeno, entre outros fatores, muitos desses centros educacionais foram inaugurados sem a devida atenção à fatores ergonômicos, gerando edificações inadequadas sob o ponto de vista humano, devido à padronização dos projetos. Assim, o presente artigo relata o processo de análise ergonômica do ambiente construído da biblioteca de um Instituto Federal de Educação Ciência e Tecnologia, recentemente instalado em uma cidade no interior de um estado do Nordeste do Brasil. Portanto, tendo em vista as peculiaridades do ambiente escolar e em específico da biblioteca, para a análise foi adotada a Metodologia para Projetos de Construção Centrados no Usuário, proposta por Attaianase e Duca (2012), seguindo o cumprimento das seguintes etapas: realização de briefing de design, definição de perfis de usuários e grupos de ajuste, análise da tarefa, adaptação às necessidades dos usuários e primeiros detalhes arquitetônicos. Dessa forma, foram identificados os pontos passíveis de melhorias ergonômicas no ambiente em questão, e tendo as problemáticas encontradas como base, foi então elaborado um projeto de interior com propostas para alterações no leiaute, dentre outras recomendações. O objetivo foi a melhoria ergonômica do ambiente construído da biblioteca analisada, buscando assim um espaço otimizado e com maior conforto para as pessoas que nele transitam.

PALAVRAS-CHAVE: ergonomia do ambiente construído; análise ergonômica; biblioteca. 


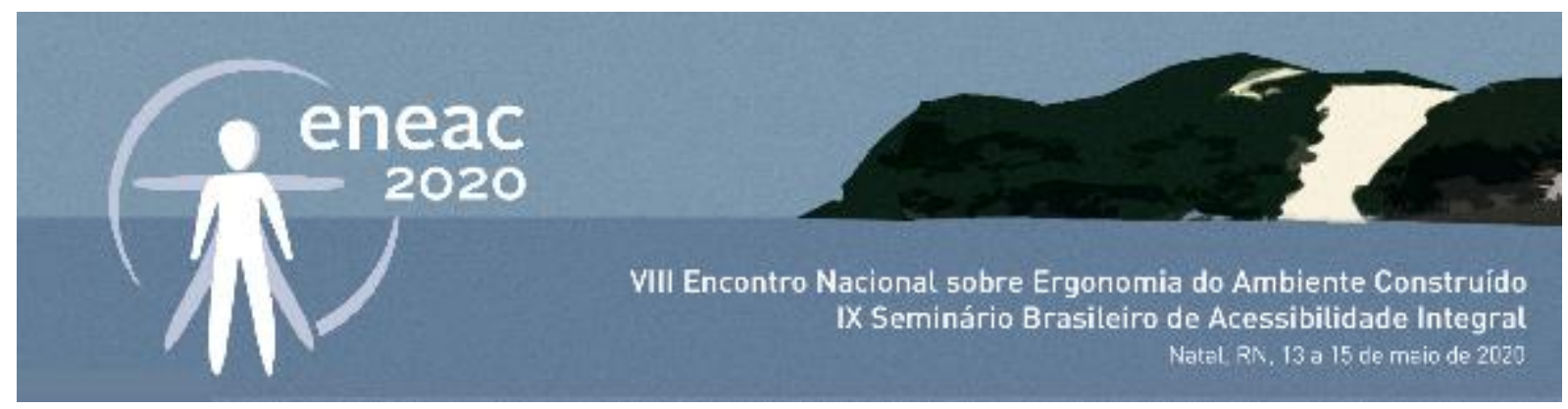

\section{ABSTRACT}

In the last two decades Universities, Federal Institutes and private institutions have intensified the process of interiorizing their campi (hitherto predominantly located in capitals), which has led to an accelerated construction of new buildings. Given the speed of the phenomenon, among other factors, many of these educational centers were opened without due attention to ergonomic factors, generating buildings that are inadequate from a human point of view, due to the standardization of projects. Thus, this article reports the process of ergonomic analysis of the built environment of the library of a Federal Institute of Education Science and Technology, recently installed in a city in the interior of a state in the Northeast of Brazil. Therefore, given the peculiarities of the school environment and specifically, the library, it was adopted for the analysis the Methodology for User-Centered Construction Projects, proposed by Attaianase and Duca (2012), following these steps: design briefing, definition of user profiles and adjustment groups, task analysis, adaptation to users' needs and first architectural details. Thus, the points that could be ergonomically improved in the environment were identified, and having the problems being pointed out, an interior design project was then elaborated with proposals for changes in the layout, among other recommendations. The goal was the ergonomic improvement of the built environment of the analyzed library, thus seeking an optimized space and greater comfort for the people utilizing it.

KEYWORDS: built environment ergonomics; ergonomic analysis; library.

\section{INTRODUÇÃO}

O presente artigo consiste na realização de uma análise ergonômica do ambiente construído através da Metodologia para Projetos de Construção Centrados no Usuário, proposta por Attaianese e Duca (2012), com o objetivo de identificar pontos passíveis de melhorias ergonômicas em um ambiente. Para alcançar tal objetivo, o local eleito para análise e aplicação da Metodologia foi a biblioteca de um Campus do Instituto Federal de Educação Ciência e Tecnologia, construído na última década em uma cidade no interior de um dos estados do Nordeste. A instituição funciona de segunda a sextafeira em três turnos, no horário das 7:30 às 22:05.

O referido Campus foi inaugurado em agosto de 2010, e a Instituição abriga diversas modalidades e níveis de ensino: técnico, médio integrado ao técnico e graduação, oferecendo os cursos de Técnico em Edificações, Técnico em Mecatrônica, Técnico em Segurança do Trabalho e Bacharelado em Engenharia Mecânica, além de diversos cursos de extensão. A instituição tem aproximadamente 800 estudantes, 100 servidores entre docentes e técnicos administrativos e 20 funcionários terceirizados. No projeto original do Campus estava prevista uma biblioteca que acabou não sendo construída na ocasião de sua inauguração, o que levou à ocupação de dois espaços originalmente projetados como salas de aula, até que a biblioteca prevista fosse construída, o que só ocorreu no ano de 2018. Porém, apesar da nova biblioteca ter sido inaugurada, seus serviços ainda funcionam no local provisório, visto que o Campus aguarda o recebimento de mobiliário para equipar o edifício. Assim, atualmente, a biblioteca funciona no local improvisado e sem previsão de mudança até o momento, no horário de segunda à sexta, das 8 h00 às 21 h00, e conta com acervo de 5 mil exemplares entre físicos e virtuais. A edificação tem área útil de $116 \mathrm{~m}^{2}$ e capacidade para 41 usuários simultâneos. Assim, após o levantamento inicial de informações e entendimento sobre a edificação como um 


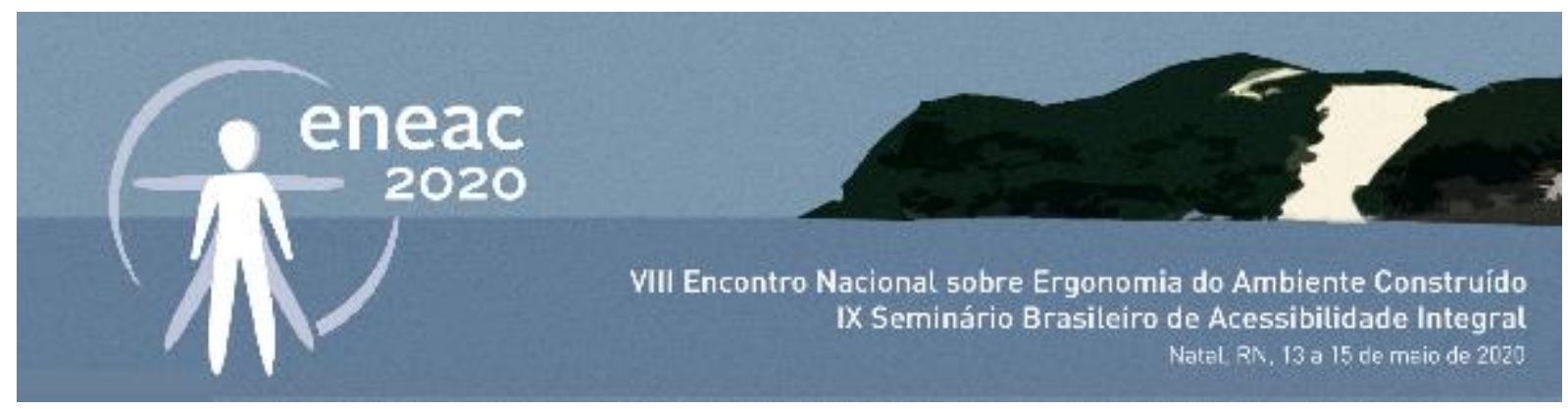

todo, o espaço da biblioteca demonstrou ser de potencial possibilidade para a aplicação da metodologia proposta, levando a equipe de trabalho a realizar a averiguação e diagnóstico do local.

\section{FUNDAMENTAÇÃO TEÓRICA}

Por serem ambientes de trabalho, bibliotecas devem seguir o que preconiza a NR 17 (BRASIL, 2016), que determina uma série de postulados para adaptar esses locais às características físicas e psicológicas dos seus profissionais. Contudo, muitos desses ambientes não seguem o que é recomendado, tornando-se lugares ergonomicamente insatisfatórios e que não atendem às necessidades humanas de seus usuários. Wilhelms (2012) afirma que o trabalho do bibliotecário, quando feito de maneira inadequada, pode desencadear acidentes e doenças relativas ao trabalho (DORT's), que podem ser geradas por transporte de documentos pesados, intensa digitação e posturas incorretas. A autora chama ainda atenção para a importância do adequado espaço para a movimentação dos membros, levando em consideração as áreas de alcance ideal, rotações do corpo e posturas em pé ou sentado, como também enfatiza o uso de cores e mobiliários adequados, assim como a existência de condições ambientais favoráveis ao ser humano.

Da mesma forma que as necessidades dos bibliotecários devem ser levadas em consideração, também é dada importância ao ato de estudo, digitação e escrita de alunos, cujos espaços também devem prezar por configurações ergonômicas adequadas, que traz vantagens como ambientes com maiores níveis de produtividade, concentração, aprendizado e com menor potencial gerador de DORT's, essenciais ao funcionamento de uma biblioteca saudável. Vasconcelos et al (2009) defendem que, a partir de uma abordagem sistêmica, tendo o usuário como foco do projeto, a identificação de elementos insatisfatórios, e uma posterior correção dos mesmos, pode promover um uso mais adequado e satisfatório da biblioteca por parte de alunos e funcionários.

lida (2005), afirma que é importante o uso da iluminação adequada para realização das tarefas, pois se sabe que a iluminância em excesso ou escassez facilita o aparecimento da fadiga visual. Neste sentido, a NBR 5413/1992 aponta que o índice de iluminância adequado para uma biblioteca deve estar entre 300 e 500Lux. Para o autor, uma zona de conforto térmico apropriada aos padrões brasileiros tem temperatura efetiva entre $20^{\circ}$ e $24^{\circ} \mathrm{C}$, com umidade relativa de 40 a $60 \%$, com a velocidade do ar na ordem $0,2 \mathrm{~m} / \mathrm{s}$ e as diferenças de temperatura em um mesmo ambiente não devem ser maiores a $4^{\circ} \mathrm{C}$. A NR-17 determina que o índice de temperatura efetiva deve estar entre $20^{\circ}$ e $23^{\circ} \mathrm{C}$ e que a velocidade do ar não deve ser superior a $0,75 \mathrm{~m} / \mathrm{s}$.

A NBR10152-Níveis de Ruído para Conforto Acústico, recomenda que o nível de ruído no ambiente de sala de aula deve estar compreendido entre 35 e 45dB. A Norma ISO 11064-6 indica que as paredes devem ter acabamentos com cores frias, poupando acabamentos escuros ou luminosos em amplas superfícies; a variação de cores e texturas deve existir para favorecer o relaxamento; deve ser evitado grandes contrastes entre mobiliários e equipamentos.

\section{METODOLOGIA}

Foi aplicada a "Metodologia para projetos de construção centrados no ser humano", de Attaianese e Duca (2012), que prevê a aplicação de sete etapas no seu roteiro: briefing de design, definição de perfis de usuários e grupos de ajuste, análise da tarefa, adaptação às necessidades dos usuários, 


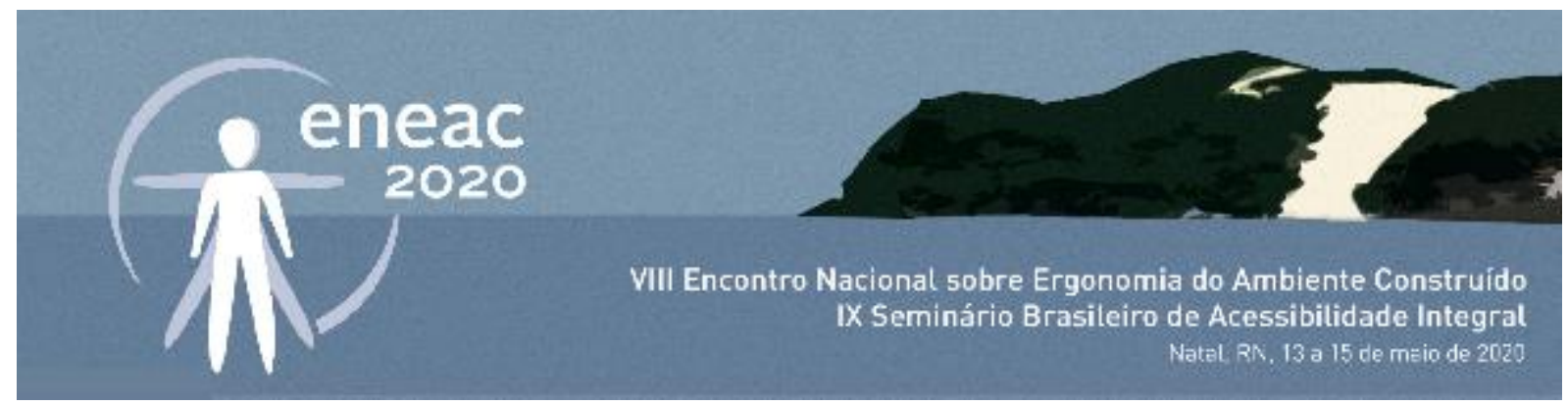

primeiros detalhes arquitetônicos, validação das soluções de design e avaliação da edificação em uso. Contudo, o presente trabalho realizou apenas as cinco primeiras, visto que nesse caso não foi possível materializar as modificações propostas para realizar a posterior avaliação. Assim, foram realizadas as etapas: briefing de design, definição de perfis de usuários e grupos de ajuste, análise da tarefa, adaptação às necessidades dos usuários e primeiros detalhes arquitetônicos.

A etapa de Briefing de Design objetivou reunir informações sobre os requisitos necessários ao ambiente para atender as necessidades dos usuários. Na segunda etapa, Perfis de Usuários e Grupos de Ajuste, foi feita a caracterização dos usuários e foram identificados os grupos de usuários (diretos, indiretos), suas características pessoais e estado de uso do ambiente. A etapa de Análise da Tarefa focou em descrever as atividades realizadas no ambiente pelos usuários, sendo verificados os requisitos necessários, e posturas corporais assumidas na realização das tarefas, condições e constrangimentos do ambiente. A quarta etapa, Adaptação às Necessidades dos Usuários, sintetizou todos os dados obtidos nas etapas anteriores, permitindo a produção de uma lista de recomendações ergonômicas. Na última etapa, Primeiros Detalhes Arquitetônicos, foi possível propor a elaboração de um projeto conceitual de referência para a instituição e usuários do espaço.

\section{RESULTADOS}

\section{Briefing de Design}

Essa etapa foca na caracterização do ambiente e o que ele precisa ter para a sua eficácia.

Observando o ambiente, entra-se na biblioteca por uma porta de giro, que dá acesso aos setores de empréstimo, acervo e consulta, onde estão localizados mobiliários para uso de estudantes e de dois servidores, um sensor de segurança contra furtos e o guarda-volumes onde os estudantes deixam as mochilas, como vê-se na Figura 01.

Figura 01: Vista do setor dos servidores, entrada, guarda-volumes e mesas de estudos.

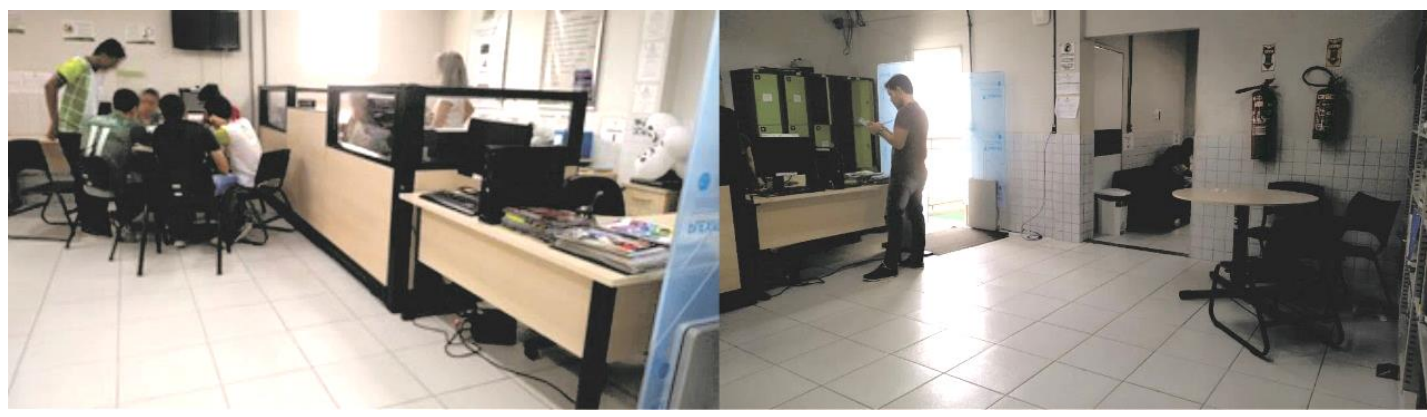

Fonte: Capturado pelos autores para a pesquisa (2020).

No espaço há uma abertura sem porta que dá acesso ao segundo ambiente da biblioteca, com mobiliário para estudo individual, em grupo e um sofá, e no local há ainda duas salas menores, uma para estudos e outra de uso do bibliotecário, conforme Figura 02. A biblioteca como um todo é climatizada por ar-condicionado e iluminada por lâmpadas fluorescentes e iluminação natural proveniente de janelas basculantes que permanecem fechadas. 


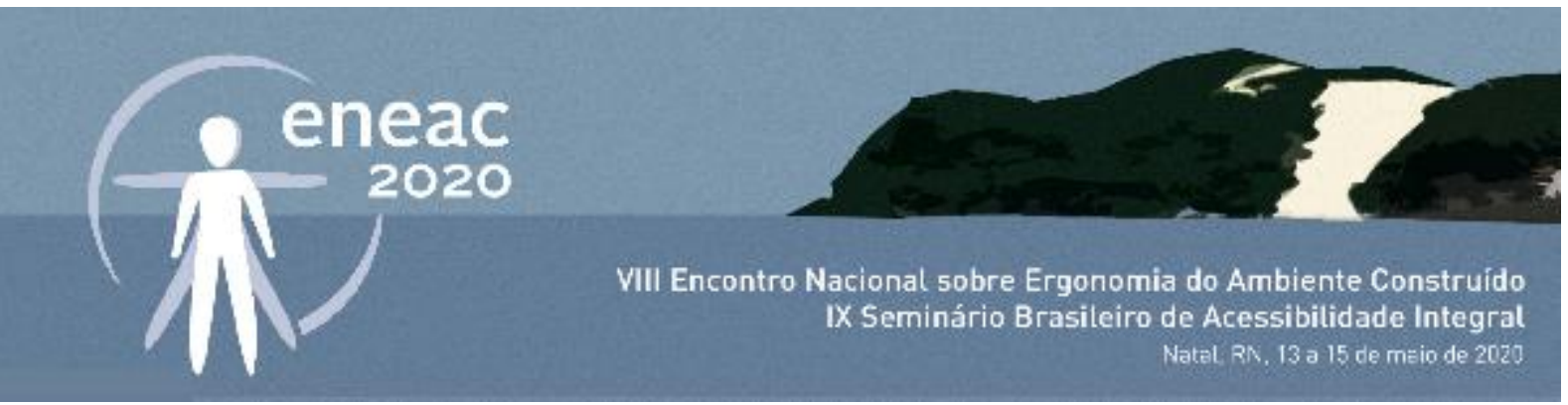

Figura 02: Vista do segundo ambiente com mesas de estudos e salas menores.

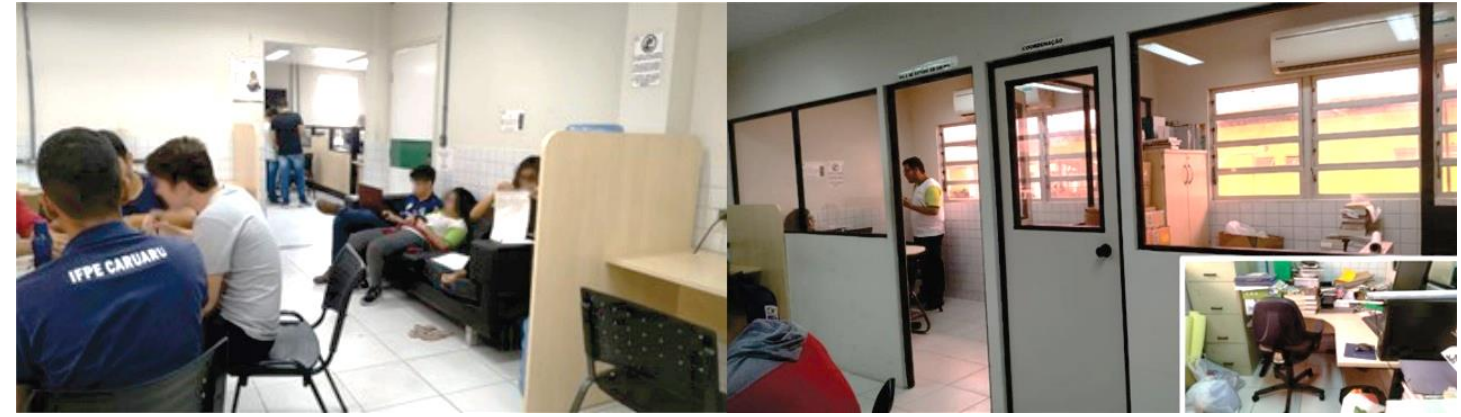

Fonte: Capturado pelos autores para a pesquisa (2020).

Podemos acompanhar, a partir da figura 03, o leiaute geral da biblioteca em análise, constando a distribuição do mobiliário pelo ambiente e áreas destinadas à circulação no ambiente.

Figura 03: Planta baixa com leiaute da biblioteca.

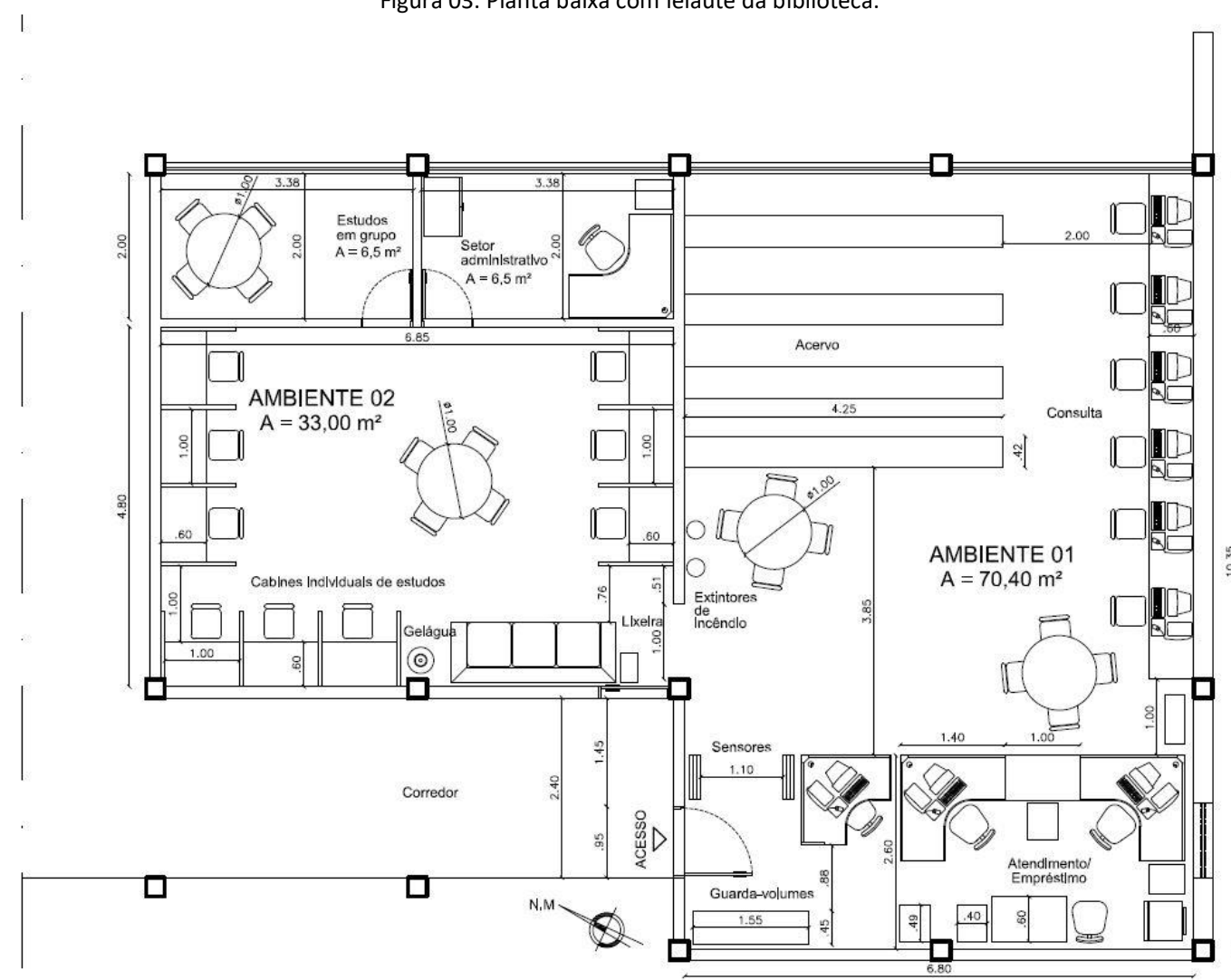

Fonte: Elaborado pelos autores tendo como base a planta baixa cedida pela Direção do Instituto (2020).

\section{Perfis de Usuários e Grupos de Ajuste}

O público que utiliza o espaço é composto de estudantes, servidores e terceirizados. Os estudantes tem em média entre 15 e 35 anos de idade, e os funcionários entre 30 e 55 e são de gêneros 


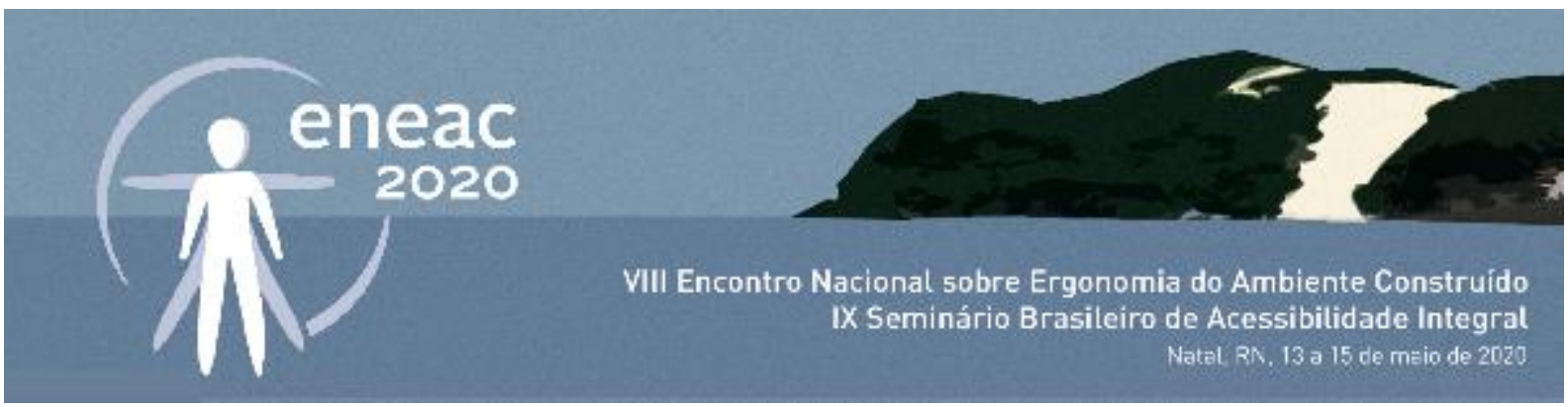

variados, o que faz com que haja no espaço pessoas com características físicas e cognitivas distintas. Através de perguntas feitas ao público do local, os dois servidores relataram que o espaço de trabalho tem mobiliário adequado, porém gostariam de um arranjo no leiaute que gerasse circulação mais ampla; os estudantes relatam que gostariam de mesas de estudo em local mais silencioso, estantes com circulação mais larga, e um acesso mais espaçoso ao balcão de empréstimos; os funcionários terceirizados relatam que se o espaço fosse mais amplo seria mais fácil trafegar com os equipamentos de limpeza. Percebeu-se, assim, que a biblioteca apresenta leiaute disfuncional com mobiliário distribuído de forma ineficiente, levando a situações que dificultam a entrada e saída do local, bem como o armazenamento de pertences dos usuários nos armários (Figura 04).

Figura 04: Mochilas no piso devido à superlotação dos armários dificultando a passagem na entrada da biblioteca.

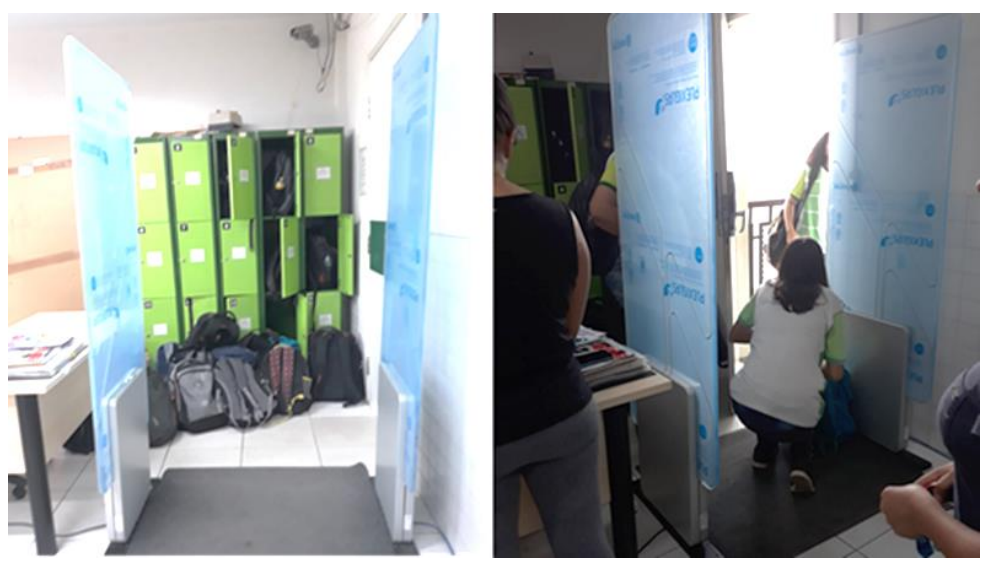

Fonte: Capturado pelos autores para a pesquisa (2020).

Os usuários também sentem dificuldades de acesso ao balcão de atendimento e para procura de livros pelas estantes (Figura 05), uma vez que trilhos no piso dificultam o acesso às estantes e a localização de mesa em frente ao balcão de atendimento obstrui o contato com o servidor que faz devoluções e empréstimos.

Figura 05: Dificuldades de utilização do espaço devido ao trilho no piso e mesa em frente ao balcão.

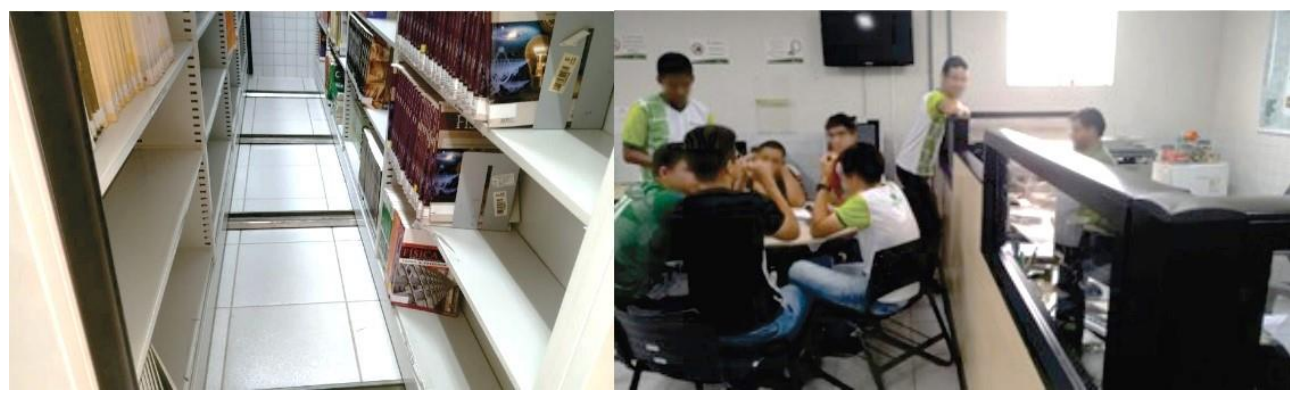

Fonte: Capturado pelos autores para a pesquisa (2020). 


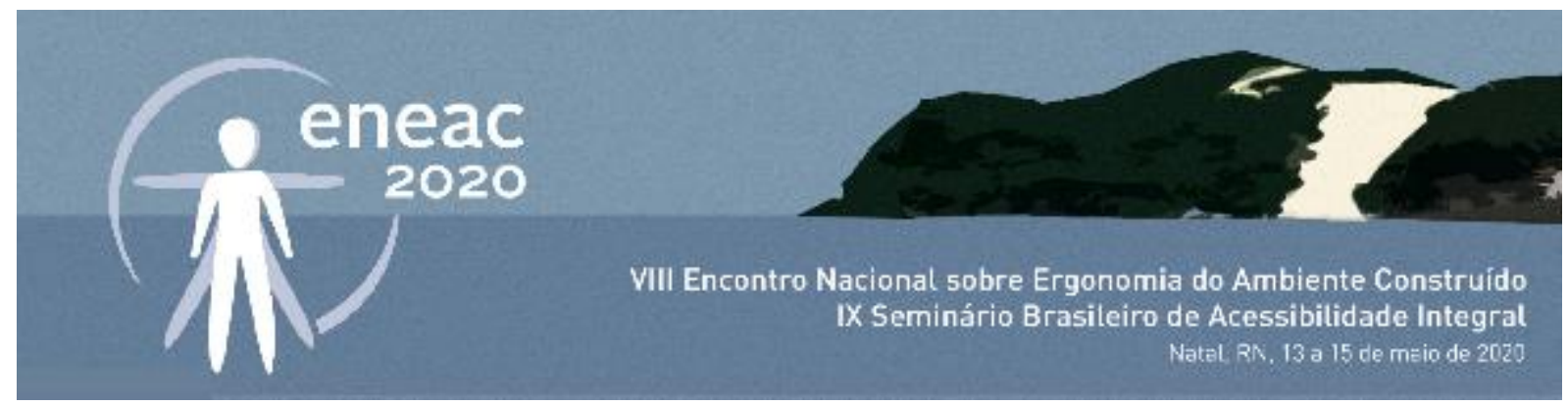

\section{Análise da Tarefa}

Esse item descreve a forma que os usuários utilizam o ambiente, e observando os alunos e funcionários, percebeu-se a adoção de posturas corporais impróprias, e muitas dessas posturas foram condicionadas pelas características do leiaute e do tipo de mobiliário. Assim, foram vistas posições prejudiciais à coluna, cabeça, membros inferiores e superiores no uso de cadeiras, mesas e acesso às prateleiras (ver Figura 06), ações que, quando repetidas em constante frequência, podem induzir ao aparecimento de Distúrbios Osteomusculares Relacionados ao Trabalho (DORT).

Figura 06: Verificação de posturas corporais inadequadas na realização de tarefas na biblioteca.

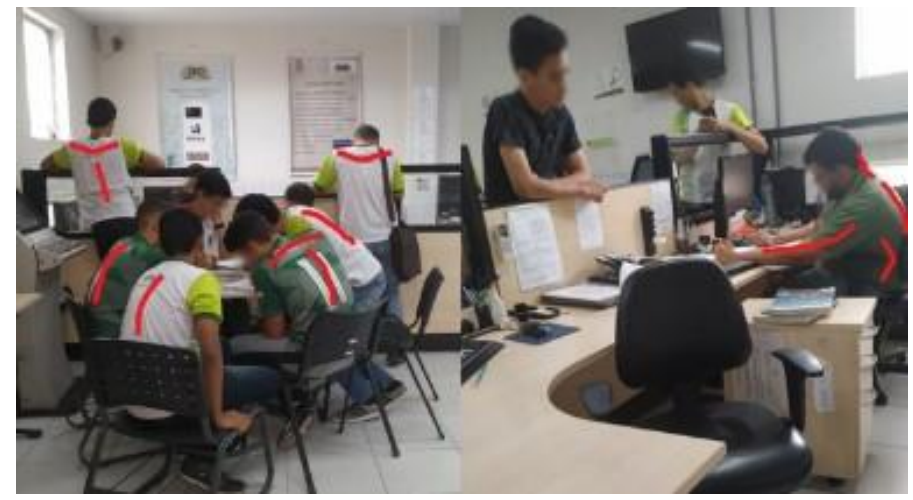

Fonte: Capturado pelos autores para a pesquisa (2020).

As constatações de inadequações foram reforçadas pela análise antropométrica das cadeiras, que demonstraram não atender à Norma NBR 13962 - 2006 e às recomendações de Panero e Zelnik (2016), conforme Figura 07.

Figura 07: Comparação entre os modelos de cadeiras existentes na biblioteca e o que preconiza as recomendações.

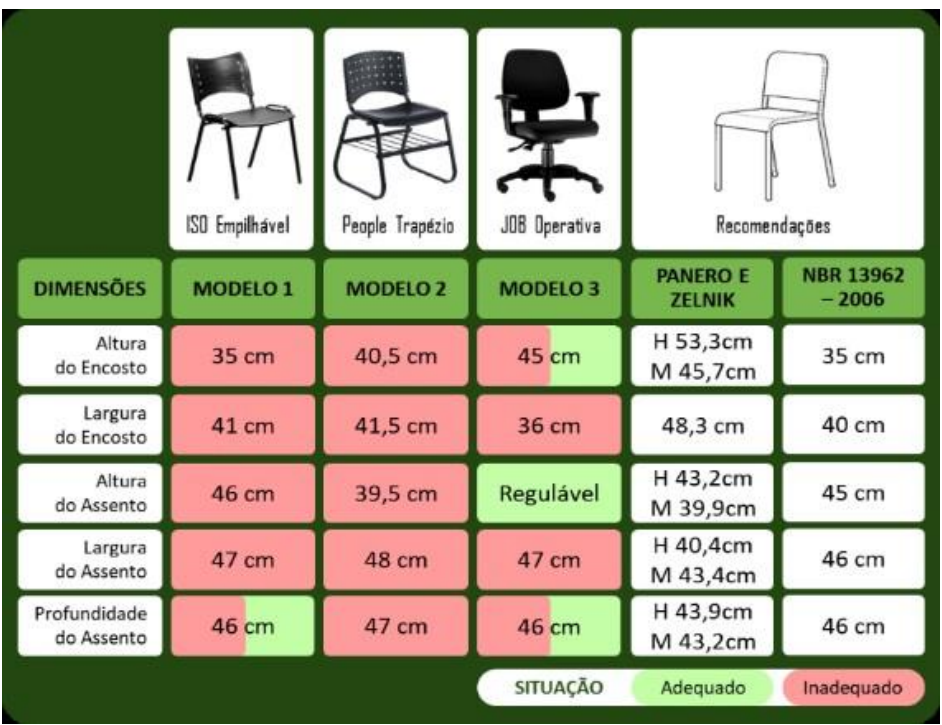

Fonte: Elaborado pelos autores para a pesquisa (2020). 


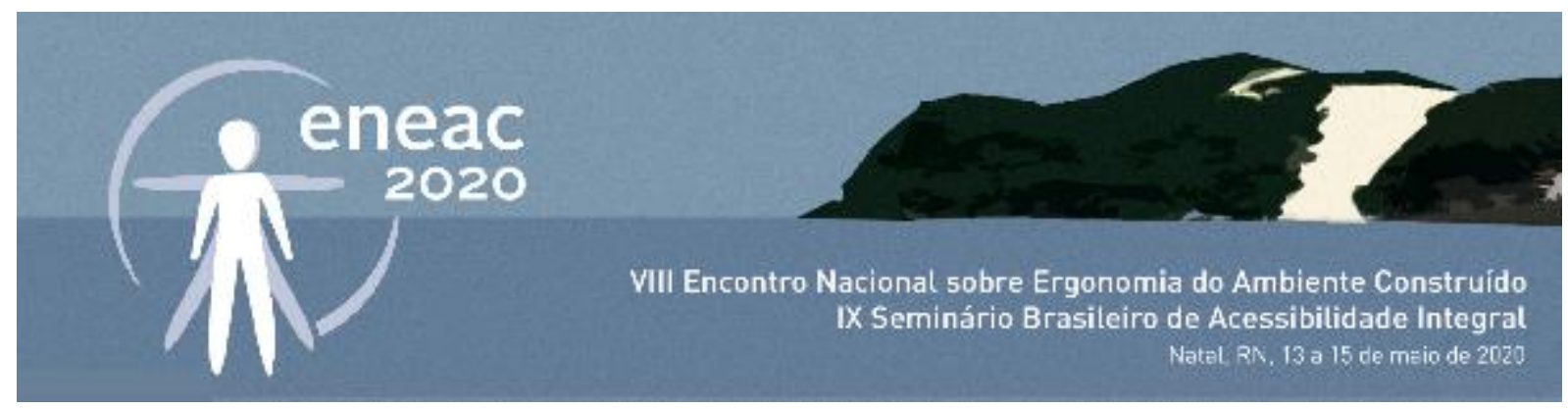

Com relação à circulação dos usuários no espaço da biblioteca, suas características puderam ser observadas através da avaliação da circulação horizontal Interna, que consistiu em realizar um diagnóstico em relação à circulação do lugar, inserindo na planta de leiaute modelos antropométricos nas cores verde, amarelo ou vermelho, indicando o nível de adequação ou inadequação. A avaliação demonstrou pontos críticos em que a circulação no ambiente estava comprometida e inadequada, conforme mostra a Figura 08.

Figura 08: Avaliação da circulação do espaço.

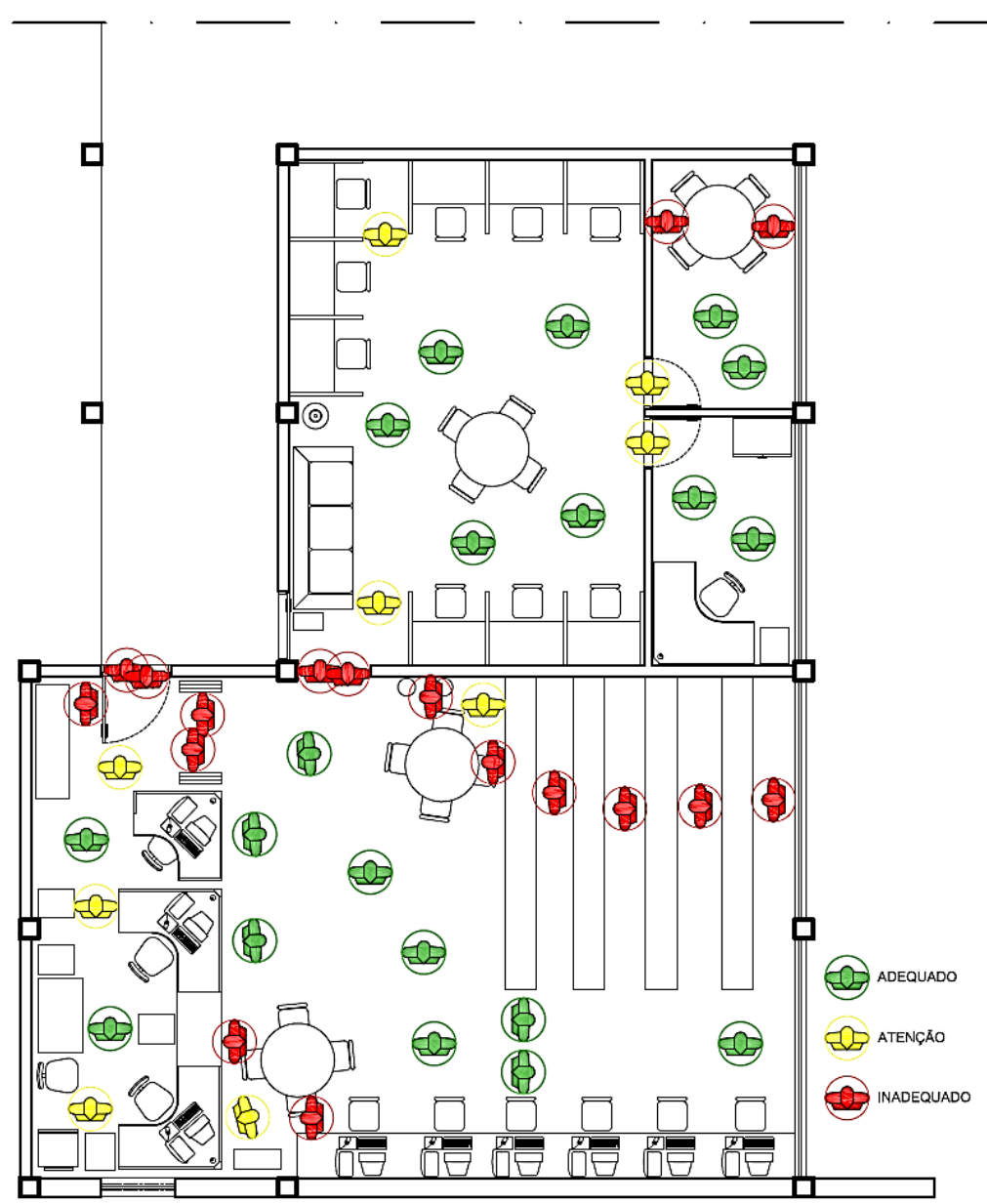

Fonte: Elaborado pelos autores para a pesquisa (2020).

No que diz respeito às análises de conforto ambiental, foram realizadas aferições em seis pontos estratégicos do ambiente: à frente do balcão de atendimento, em uma das mesas de estudos em grupo, no setor de consulta aos computadores, em duas das cabines de estudos individuais e no interior da sala de estudos em grupo, onde foram utilizados aparelhos de conformidade obrigatória recentemente calibrados da marca UNI-T. Para verificar o índice de iluminação, foi utilizado o Luxímetro, que mede o índice de Lux no ambiente. Por sua vez, para verificar o índice de 


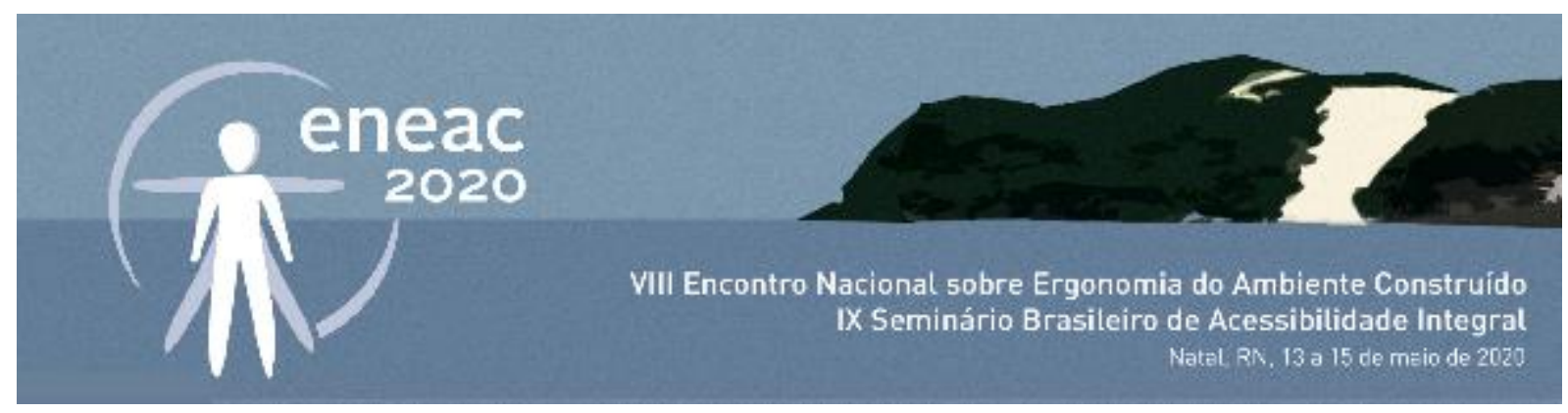

temperatura, foi utilizado o Termoanemômetro e por fim, para analisar o índice de decibéis no ambiente foi utilizado o Decibelímetro. Dessa maneira, foi possível realizar comparativos entre as medições realizadas e as recomendações das Normas técnicas em busca de averiguar a adequação das medidas encontradas. A NBR 5413/ 1992 recomenda bibliotecas tenham índices entre 300 - 500 750 lux, e as medições no local apresentaram resultados que variaram entre 523 e 1300 nos períodos diurno e noturno, demonstrando que há pontos em que a luminância é excessiva. Com relação à temperatura, a NBR $6401 / 1980$ preconiza que deva ser entre $24^{\circ} \mathrm{C}$ e $26^{\circ} \mathrm{C}$, contudo as medições apontaram temperaturas entre $24^{\circ} \mathrm{C}$ e $28^{\circ} \mathrm{C}$, inclusive no turno da noite, o que reforça a ineficiência do ar refrigerado. Já no que diz respeito aos níveis de ruído estes foram mais alarmantes, visto que o recomendado pela NBR 10152/1987 é $30-45 \mathrm{~dB}$, e no local foram identificados ruídos de $54.3 \mathrm{~dB}$ até $67.8 \mathrm{~dB}$, algo inadequado ao ambiente de uma biblioteca.

\section{Adaptação às Necessidades do Usuário}

Essa fase sintetizou as inadequações ergonômicas encontradas e ressaltou as adaptações necessárias, com as recomendações ergonômicas e suas justificativas. Tendo em vista os problemas identificados, ficou evidente a necessidade de realizar intervenções no espaço através de um projeto de interiores que procurasse sanar as falhas ergonômicas existentes, otimizando assim o uso do local por todos os usuários da comunidade acadêmica do Campus, conforme demonstra o Quadro 01:

Tabela 01: Recomendações ergonômicas e suas justificativas.

\begin{tabular}{|c|c|}
\hline RECOMENDAÇÕES ERGONÔMICAS & JUSTIFICATIVA \\
\hline $\begin{array}{l}\text { Reconfigurar o leiaute da biblioteca organizando o } \\
\text { ambiente em áreas específicas e funcionais. }\end{array}$ & $\begin{array}{l}\text { Atividades ocorrerão de forma que um setor não exerça } \\
\text { interferência sobre o outro, algo que atualmente acontece. }\end{array}$ \\
\hline $\begin{array}{l}\text { Criar novas salas de estudo em grupo com recursos } \\
\text { didáticos (lousa e acessórios) e realocar as mesas do } \\
\text { salão para esses novos espaços. }\end{array}$ & $\begin{array}{l}\text { As mesas atrapalham o fluxo e dificultam o acesso a } \\
\text { determinadas áreas, além de que o barulho feito pelos grupos } \\
\text { de estudantes interfere na concentração dos demais. }\end{array}$ \\
\hline $\begin{array}{l}\text { Criar uma entrada e passagem ampla com porta em } \\
\text { duas folhas para circulação adequada e confortável, } \\
\text { com acessibilidade (puxador, visor e protetor para } \\
\text { impacto) e possibilidade de saída de emergência. }\end{array}$ & $\begin{array}{l}\text { A entrada e passagem atuais são estreitas e não permitem } \\
\text { circulação adequada, além de promover insegurança contra } \\
\text { evacuação por incêndio. }\end{array}$ \\
\hline $\begin{array}{l}\text { Colocar o guarda-volumes na área externa próximo a } \\
\text { porta de acesso e adquirir mais armários compatíveis } \\
\text { com a capacidade total de usuários. }\end{array}$ & $\begin{array}{l}\text { Guardar as mochilas de todos que estão utilizando o ambiente, } \\
\text { evitando que elas permaneçam no piso obstruindo a abertura } \\
\text { da porta e o acesso à área de trabalho dos funcionários. }\end{array}$ \\
\hline Retirar o sofá do ambiente. & $\begin{array}{l}\text { A presença do sofá induz os alunos a utilizarem-no de forma } \\
\text { inadequada e assumirem posturas nocivas. Também leva-os a } \\
\text { conversas e geração de ruídos a quem está estudando. }\end{array}$ \\
\hline $\begin{array}{l}\text { Colocar estantes/prateleiras na área de trabalho dos } \\
\text { bibliotecários, alterando leiaute e removendo os } \\
\text { materiais em desuso para o depósito do Campus. }\end{array}$ & $\begin{array}{l}\text { Essas mudanças vão liberar as mesas e o piso, guardando os } \\
\text { livros e demais objetos em local adequado e gerando um } \\
\text { melhor fluxo de circulação. }\end{array}$ \\
\hline $\begin{array}{l}\text { Criar um espaço exclusivo para pesquisa e estudo, } \\
\text { com bancadas individuais e distante da área de maior }\end{array}$ & $\begin{array}{l}\text { Garantir um ambiente propício à pesquisa e estudo, } \\
\text { proporcionando maior silêncio e tranquilidade aos estudantes. }\end{array}$ \\
\hline
\end{tabular}




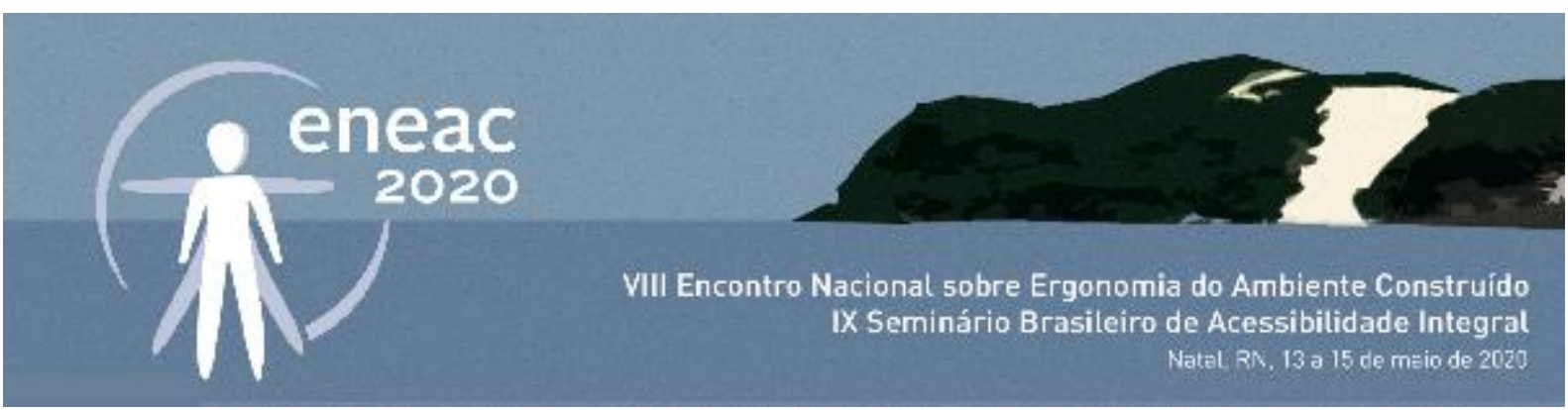

\begin{tabular}{|c|c|}
\hline fluxo de usuários. & \\
\hline $\begin{array}{l}\text { Aumentar o espaço entre as estantes, tornando-as } \\
\text { fixas, retirando os trilhos e manivelas. }\end{array}$ & $\begin{array}{l}\text { Os trilhos no piso interrompem a livre circulação e podem gerar } \\
\text { acidentes, além de gerar corredores estreitos. Com a ação gera- } \\
\text { se corredores acessiveis para circulação de quem procura pelos } \\
\text { livros e livra-os de obstáculos. }\end{array}$ \\
\hline Instalar cortinas nas janelas. & $\begin{array}{l}\text { Promover maior conforto ambiental protegendo usuários de } \\
\text { iluminação excessiva e ofuscante. }\end{array}$ \\
\hline $\begin{array}{l}\text { Criar um espaço de estudo exclusivo para } \\
\text { cadeirantes, com mobiliário nas medidas compatíveis } \\
\text { com a NBR 9050. É preferível que o mobiliário seja } \\
\text { regulável para adaptar-se à altura da cadeira de } \\
\text { rodas. }\end{array}$ & $\begin{array}{l}\text { Com isso, atende-se às necessidades específicas de um público } \\
\text { que até então, não foi considerado na configuração do } \\
\text { ambiente. }\end{array}$ \\
\hline $\begin{array}{l}\text { Realocar objetos como totem de pesquisa e } \\
\text { extintores de incêndio. }\end{array}$ & $\begin{array}{l}\text { Atualmente estão em locais que obstruem a passagem. Busca- } \\
\text { se torná-los acessíveis quando forem necessários sem causar } \\
\text { incômodos à circulação. }\end{array}$ \\
\hline $\begin{array}{l}\text { Reposicionar o setor técnico (sala de coordenação e } \\
\text { conferência) para área de contato direto com o } \\
\text { corredor externo. }\end{array}$ & $\begin{array}{l}\text { Dessa forma, a recepção de livros e materiais didáticos ocorre } \\
\text { diretamente no setor responsável, evitando interferência nos } \\
\text { demais fluxos da biblioteca, além de aglutinar todo o setor } \\
\text { administrativo. }\end{array}$ \\
\hline $\begin{array}{l}\text { Criar sistema de sinalização padronizado, com } \\
\text { manual completo seguindo a identidade visual do } \\
\text { Instituto, acrescido de informações em Braille e } \\
\text { acessível a todos os grupos de usuários. }\end{array}$ & $\begin{array}{l}\text { O espaço conta com sinalização informal e deficitária, sem } \\
\text { padronização e sem acessibilidade para deficientes visuais. }\end{array}$ \\
\hline $\begin{array}{l}\text { Pintar as paredes em cores estimulantes como verde, } \\
\text { laranja e branco. }\end{array}$ & $\begin{array}{l}\text { As paredes brancas criaram um ambiente monótono e } \\
\text { inadequado às atividades de estudo. A mudança busca } \\
\text { preservar à identidade do Campus levando vitalidade e calma } \\
\text { com o verde, provocar estímulo e criatividade com o laranja e } \\
\text { manter a claridade com o branco. }\end{array}$ \\
\hline
\end{tabular}

Fonte: Elaborado pelos autores para a pesquisa (2020).

Todas essas recomendações foram propostas tendo como base as necessidades dos usuários observadas durante a visita de avaliação do ambiente, e as análises, diagnósticos e medições realizadas pela equipe, e permitiram a elaboração de um projeto com nova proposta de leiaute.

\section{Primeiros Detalhes Arquitetônicos}

A última etapa consistiu em demonstrar os desenhos técnicos e renders digitais do projeto proposto, de forma a atender às recomendações ergonômicas de modo objetivo e factível ao espaço em questão. Dadas as características próprias do Instituto, uma instituição educacional pública vinculada ao Governo Federal, esta possui particularidades próprias quanto à compra de novos equipamentos e mobiliários, visto que depende de aprovação de orçamentos e de realização de processos licitatórios e pregões. Por esse motivo, decidiu-se aproveitar o máximo possível os bens existentes no espaço, realizando intervenções que não trouxessem grandes impactos financeiros à instituição, fato que poderia inviabilizar uma possível aplicação do projeto. Assim, o foco da proposta foi realocar o 


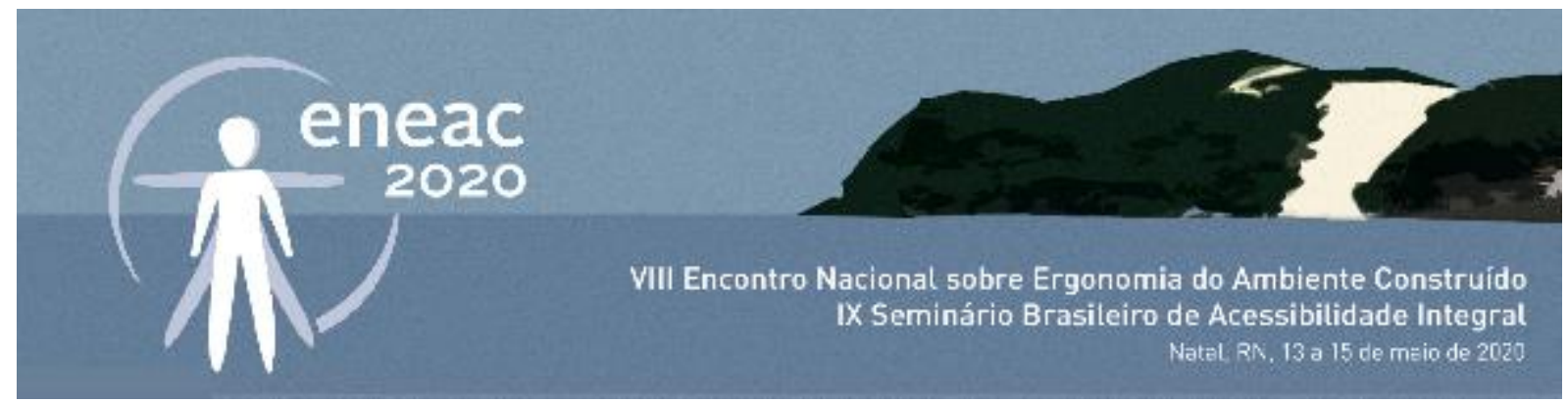

mobiliário existente, realizar algumas demolições de paredes e construção de divisórias, substituir algumas portas, realocar pontos de luz, interruptores e tomadas, e troca da pintura do local. Assim, de acordo com esses direcionamentos, foi desenvolvida uma nova configuração de leiaute do espaço, demonstrada na planta baixa a seguir (Figura 09):

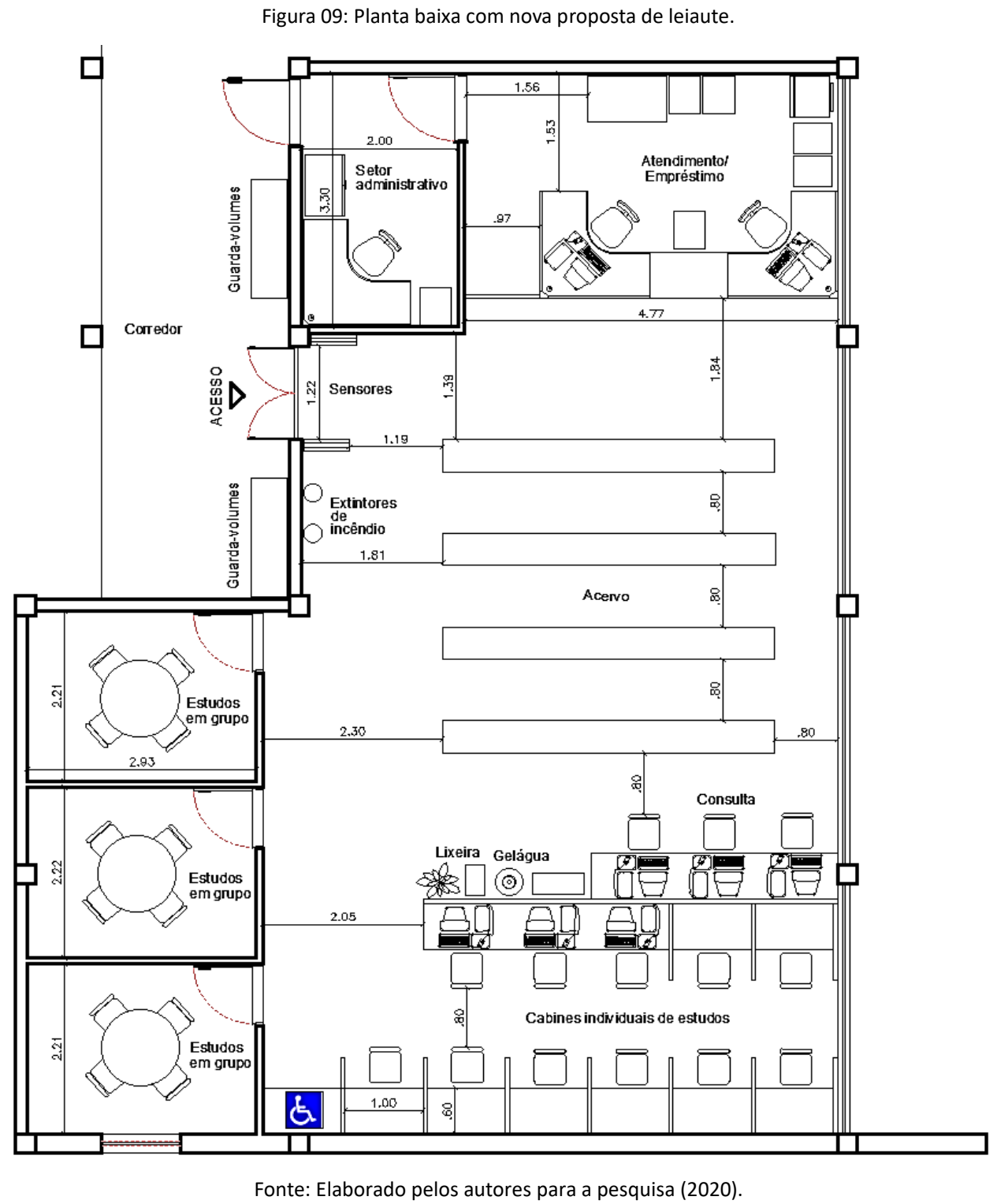

De forma a verificar e validar se com o novo leiaute houve melhoria nos parâmetros de circulação, reaplicamos a avaliação da circulação horizontal interna e, através dela, foi possível perceber (Figura 10) uma visível otimização na configuração proposta, especialmente nos acessos e área de acervo. 

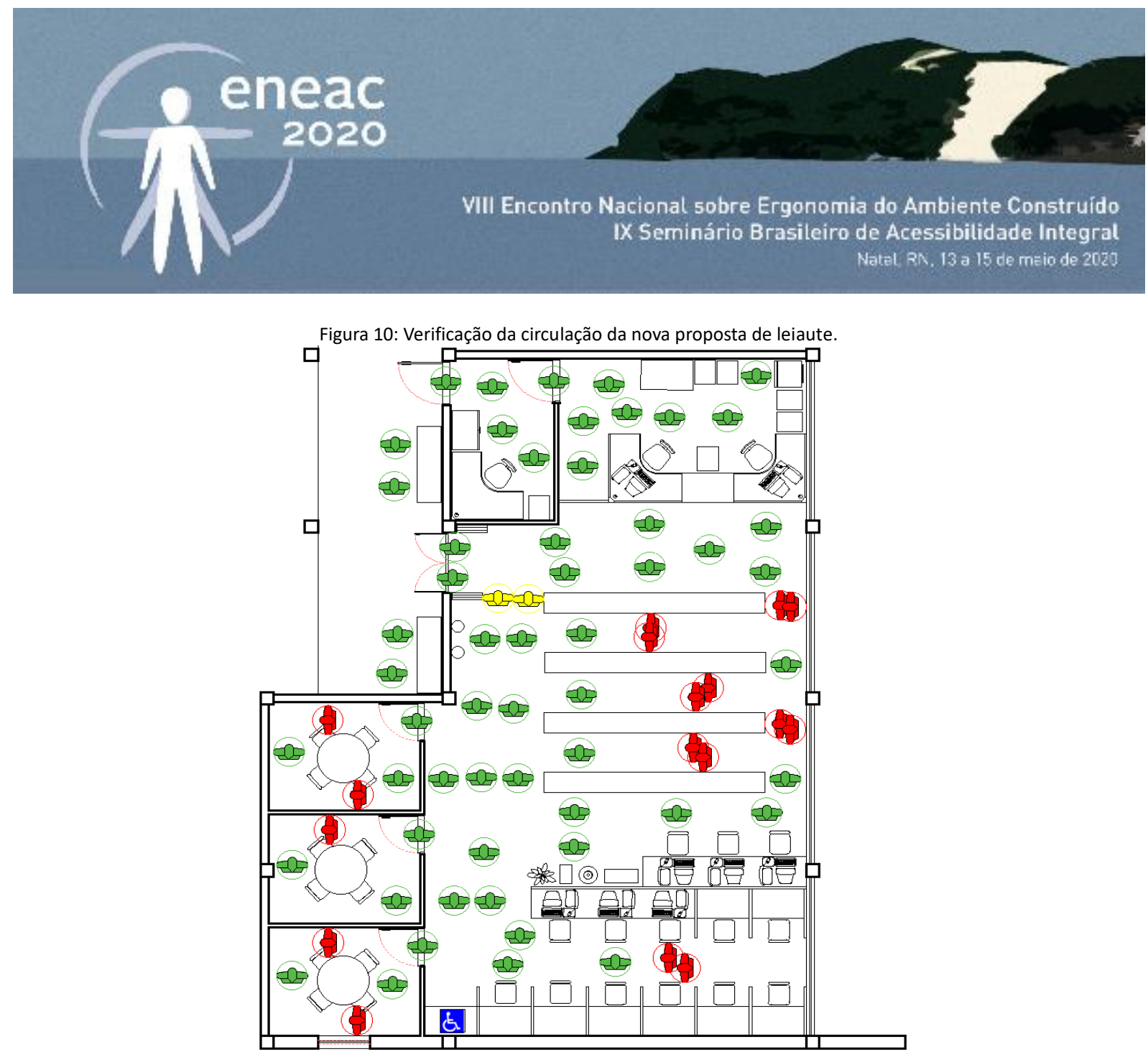

Fonte: Elaborado pelos autores para a pesquisa (2020).

O novo leiaute propõe uma mudança no acesso à biblioteca, eliminando as portas antigas e abrindo um novo acesso pela parede lateral. Nesse acesso, o vão da porta foi alargado para 1,22m, para permitir melhor circulação dos usuários, inclusive para cadeirantes. Foram especificadas portas de vidro sinalizadas e abrindo para fora, seguindo o que é recomendado para rotas de fuga em caso de incêndios, além da transparência parcial permitir a permeabilidade visual entre interior e exterior do recinto. Os armários de guarda-volumes foram alocados do lado de fora da biblioteca (Figura 11).

Figura 11: Render digital da nova entrada proposta, com os armários no corredor.

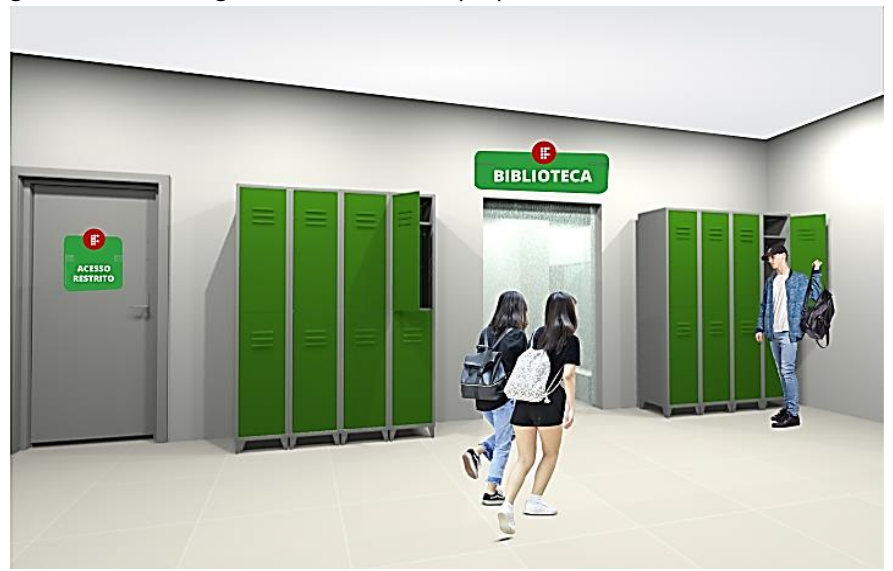

Fonte: Elaborado pelos autores para a pesquisa (2020). 


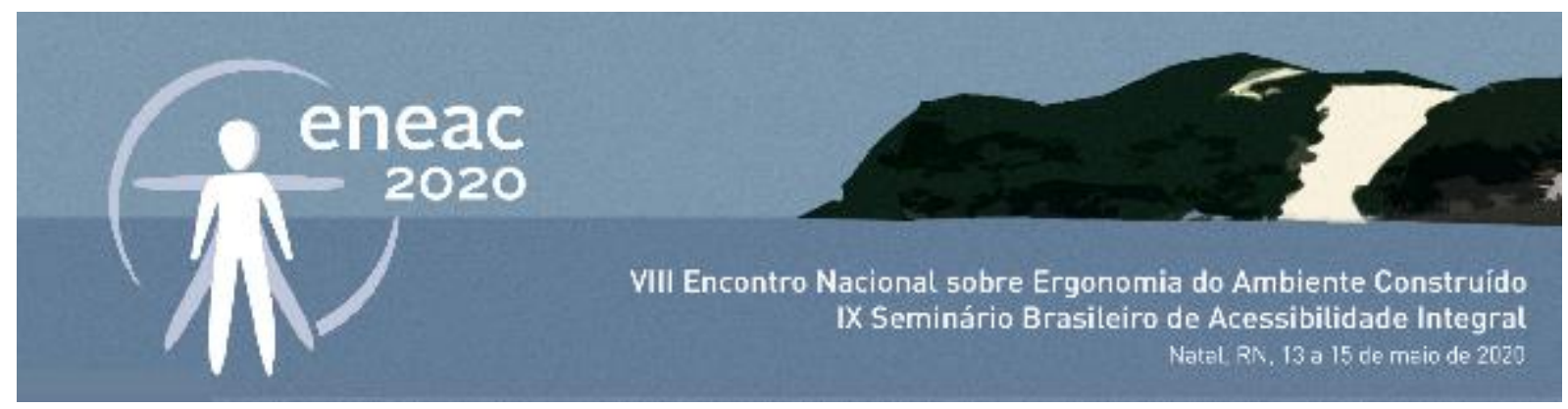

Com os armários dispostos no corredor, aproveita-se o espaço amplo de circulação dessa área e evitase a aglomeração de pessoas dentro do setor, sugerindo-se ainda a compra de mais armários para dobrar a capacidade de armazenamento e evitar que as mochilas sejam deixadas no chão.

Os postos de trabalho dos servidores foram aglutinados em uma mesma área, fazendo com que a sala da coordenação ficasse ao lado do balcão de empréstimos. A localização da sala também permitiu uma abertura para o corredor externo, para que quando cheguem novos materiais, o bibliotecário possa recebê-los e catalogá-los para incorporar às estantes, com um fluxo independente do restante do espaço. Esse arranjo também permite que os servidores tenham maior proximidade e trabalhem em conjunto de forma mais otimizada e integrada. Além disso, sugerindo-se que haja apenas duas mesas de trabalho (reaproveitando a terceira para outro setor do Campus), consegue-se mais espaço para circulação com a criação de um corredor lateral e maior área por trás das mesas, já que os servidores se revezam em turnos de trabalho em duplas.

Sugere-se ainda a incorporação de algumas prateleiras aéreas para alocar materiais de forma adequada, e o que fosse pertinente, seria levado para depósitos ou almoxarifados do Campus, livrando o local de acúmulo de itens desnecessários pelo piso. Por sua vez, a localização próxima da entrada e das estantes do acervo também é estratégica ao trabalho, assim como ao fluxo do público da biblioteca, que pode acessar o balcão e o acervo de forma direta e com facilidade, dado o amplo espaço deixado na frente do setor. Com relação ao acervo, foi proposto que os trilhos das estantes fossem retirados, e que elas sejam apoiadas diretamente no piso, com largura fixa entre si de $0,80 \mathrm{~m}$, garantindo uma circulação adequada em todo seu perímetro, sem que estas encostem em obstáculos, motivo pelo qual pensou-se em demolir a parede que divide os dois ambientes, o que conferiu maior amplitude espacial e visual ao local. Os extintores de incêndio e sensores anti-furto foram posicionados de forma a não interferir nos fluxos, garantindo a segurança dos usuários e funcionamento regular do espaço.

O lixeiro e o bebedouro foram agrupados no ambiente de estudos, com adequado espaço de circulação à frente e de fácil visualização e acesso, e a inserção de vegetação em vaso conferiu um aspecto ambiental agradável (ver Figura 12), característico da presença da natureza.

Figura 12: Render digital da área de pesquisa e estudos individuais.

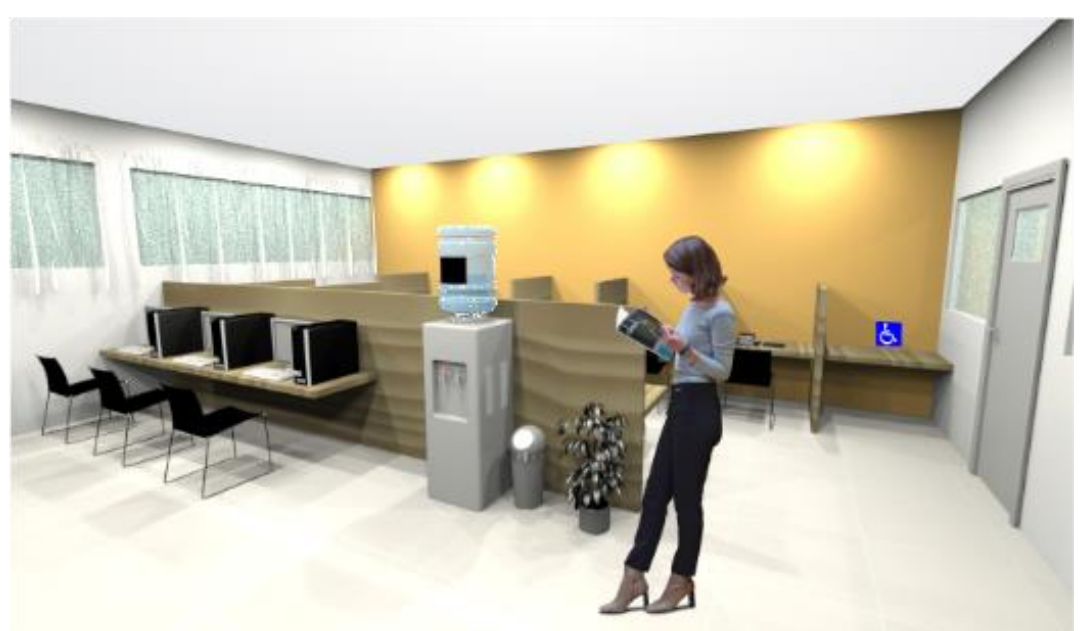

Fonte: Elaborado pelos autores para a pesquisa (2020). 


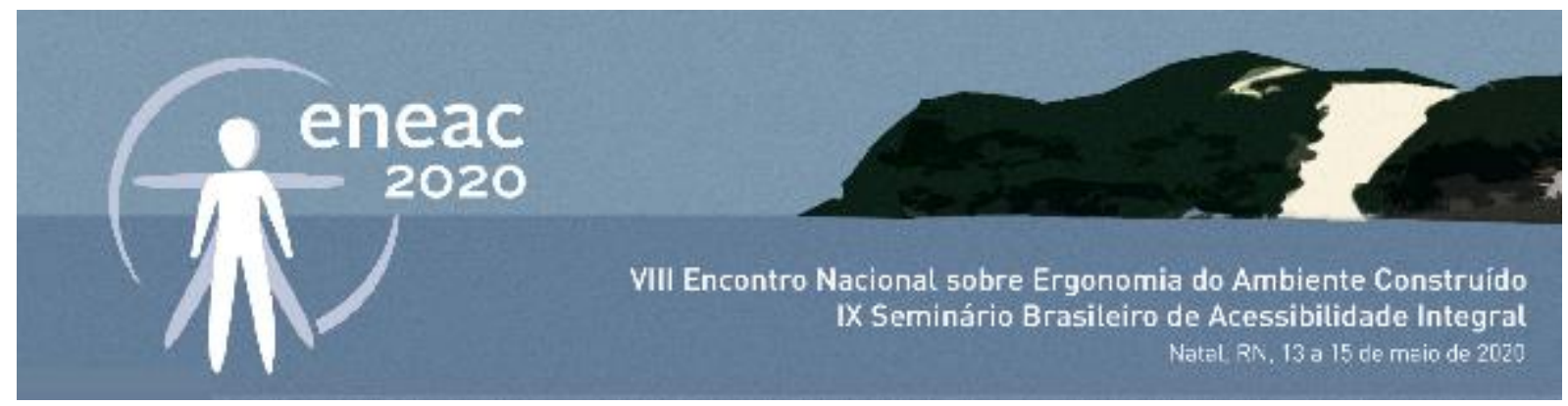

No tocante às atividades de estudos em grupo e de forma individual, foram destinadas áreas com barreiras físicas entre as diferentes atividades. Para estudos coletivos, foram criadas três salas independentes, onde além das mesas e cadeiras, propõe-se a inserção de lousas para resolução de exercícios, e portas de largura compatível à passagem de cadeiras-de-rodas. A figura 13 que se segue apresenta uma visão geral do projeto.

Figura 13: Render digital com vista superior geral do projeto proposto.

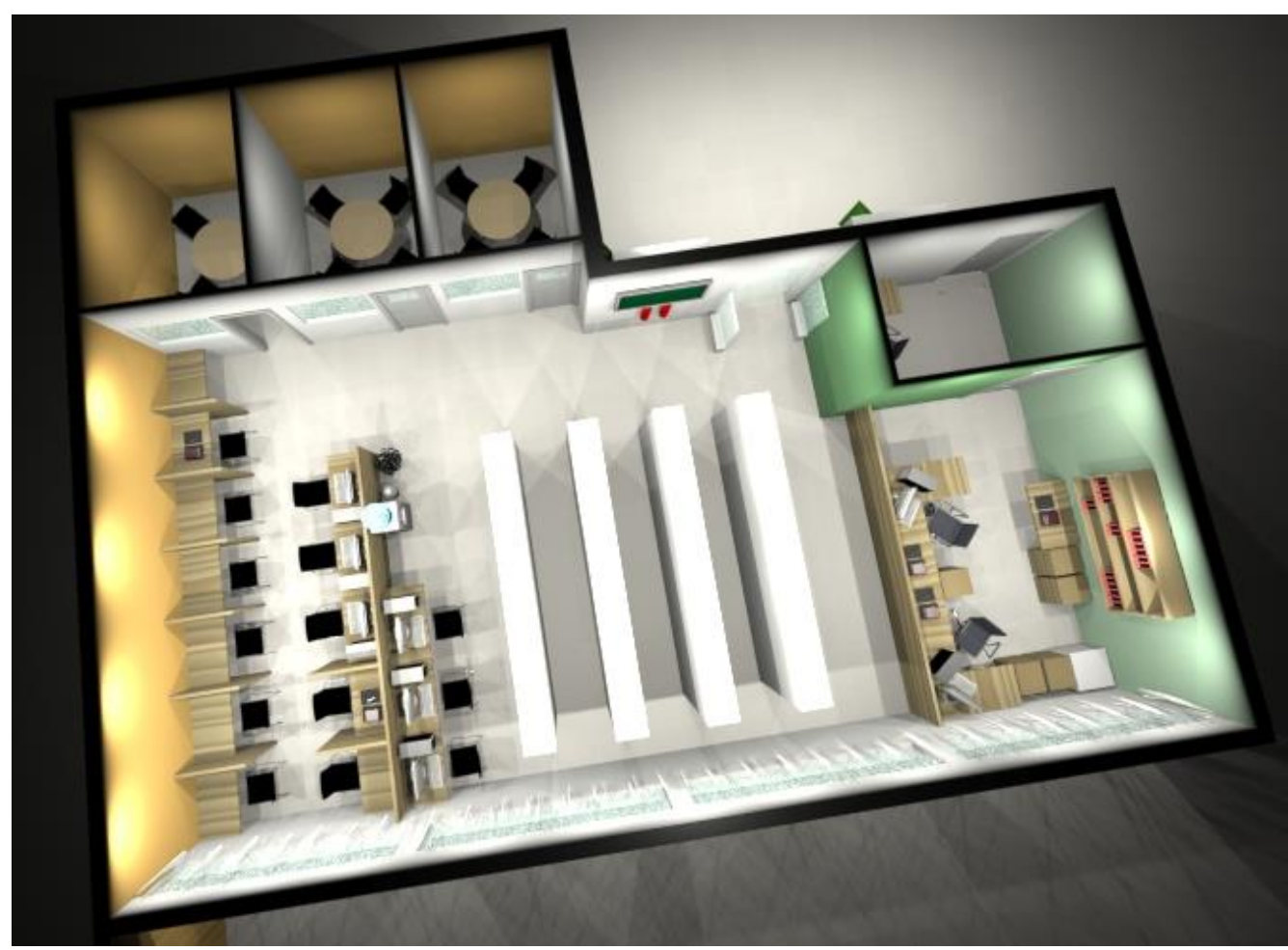

Fonte: Elaborado pelos autores para a pesquisa (2020).

As cabines para estudo individual e mesas com computadores para pesquisa foram agrupadas em um local mais reservado ao fundo, sem previsão da interferência de conversas de outros usuários, visto que permitem a ocupação de apenas uma pessoa por cabine, sem mobiliários de uso coletivo por perto, estimulando o silêncio, e nessa área foi incluída uma cabine sinalizada para uso exclusivo de usuário cadeirante.

\section{CONCLUSÃO}

Através das análises e resultados, percebeu-se que o fato da biblioteca funcionar em um local previamente projetado para ter outro uso não deveria ser um motivo para que a mesma tenha uma configuração ergonômica deficitária. Foi possível constatar que, com o mesmo mobiliário e algumas intervenções pontuais, a biblioteca tem condições de ser um ambiente ergonomicamente satisfatório, permitindo melhor qualidade de trabalho aos servidores e maior desempenho intelectual aos estudantes que nela permanecem. 


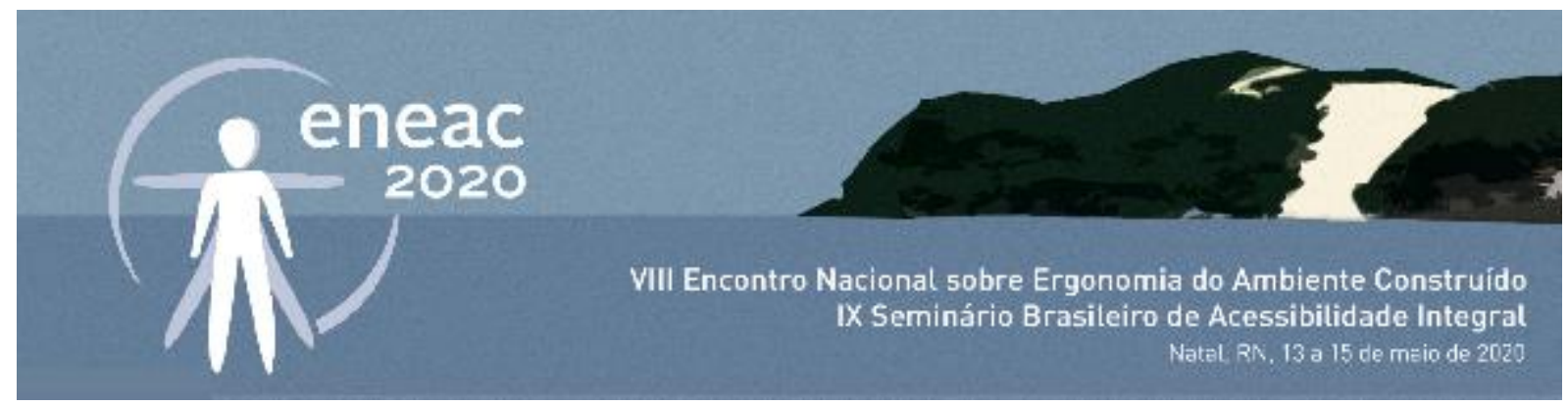

A pesquisa evidencia o fato de que grandes campi deveriam ter setores internos de ergonomia, os quais controlassem a adequação de projetos e edificações já erguidas com foco central no ser humano. A investigação expôs o fato de que a Ergonomia se revela como fator essencial para a qualidade de vida no desempenho das atividades no ambiente da biblioteca e, consequentemente, na qualidade do processo de estudo, assimilação de conhecimento e aprendizagem neste tipo de ambiente.

A Metodologia para Projetos de Construção Centrados no Usuário revelou sua eficácia a partir do momento em que propôs etapas investigativas detalhadas, as quais, ao serem seguidas, conduziram os pesquisadores à descoberta de diversas inadequações no ambiente interno da biblioteca. A etapa denominada de Primeiros Detalhes Arquitetônicos guiou a elaboração de um projeto conceitual, o qual, no momento de submissão do corrente trabalho, está em fase de explanação e viabilização de implantação por parte da instituição de ensino. Após a implantação do projeto, novas pesquisas serão realizadas no sentido de verificar a eficácia das recomendações após sua aplicação, atendendo também à última etapa proposta pela metodologia.

\section{REFERÊNCIAS}

ASSOCIAÇÃO BRASILEIRA DE NORMAS TÉCNICAS. NBR 10152. Níveis de ruído para conforto acústico. Rio de Janeiro, p. 4. Disponível em: <http://www.joaopessoa.pb.gov.br/portal/wp-content/uploads/2015/02/NBR_10152-1987-ConfortoAc_stico.pdf> Acesso em: 11 de novembro de 2019.

ASSOCIAÇÃO BRASILEIRA DE NORMAS TÉCNICAS. NBR 13962:2006. Móveis para escritório - Cadeiras - Requisitos e métodos de ensaio. Rio de Janeiro, p. 30. Disponível em: <http://www.camarasete.mg.gov.br/licitacoes/arqui_licita_anexo_0247.pdf> Acesso em:14 de novembro de 2019.

ASSOCIAÇÃO BRASILEIRA DE NORMAS TÉCNICAS. NBR 5382. Verificação de iluminação de interiores. Rio de Janeiro, p. 4. Disponível em: <https://www.docsity.com/pt/nbr-5382-verificacao-de-iluminancia-de-interiores/4808798/> Acesso em: 11 de novembro de 2019.

ASSOCIAÇÃO BRASILEIRA DE NORMAS TÉCNICAS. NBR 5413. Iluminância de interiores. Rio de Janeiro, p. 13. Disponível em: <http://ftp.demec.ufpr.br/disciplinas/TM802/NBR5413.pdf> Acesso em: 11 de novembro de 2019.

ASSOCIAÇÃO BRASILEIRA DE NORMAS TÉCNICAS. NBR 6401. Instalações centrais de ar-condicionado para conforto Parâmetros básicos de projeto. Rio de Janeiro, p. 17. Disponível em:

<https://www.refrigeracao.net/Legislacao/NBR6401.pdf> Acesso em: 11 de novembro de 2019.

ATTAIANESE, E.; DUCA, G. Human factors and ergonomic principles in building design for life and work activities: an applied methodology. Theoretical Issues in Ergonomics Science. Vol. 13, No. 2, March-April 2012, 187-202.

BRASIL. Ministério do Trabalho e Previdência Social. NR 17. Ergonomia. p. 14. Disponível em: <https://www.pncq.org.br/uploads/2016/NR_MTE/NR\%2017\%20-\%20ERGONOMIA.pdf> Acesso em: 11 de novembro de 2019.

IIDA, Itiro. Egonomia: projeto e produção. 2a edição. São Paulo: Edgard Blucher, 2005.

PANERO, J.; ZELNIK, M. Dimensionamento humano para espaços interiores. 1. Ed. Barcelona: Gustavo Gilli, SL, 2016.

VASCONCELOS, C. S. F. e; VILLAROUCO, V.; SOARES, M. M. Avaliação Ergonômica do Ambiente Construído: Estudo de caso em uma biblioteca universitária. Ação ergonômica, Revista Brasileira de Ergonomia, v. 4, n. 1, p. 5-25, 2009. Disponível em: <http://www.abergo.org.br/revista/index.php/ae/article/view/69> Acesso em: 11 de setembro de 2019.

WILHELMS, Tânia Marli Stasiak. Ergonomia em Bibliotecas. In: SANTOS, Jussara Pereira. Gestão Ambiental em Bibliotecas: aspectos interdisciplinares sobre ergonomia, segurança, condicionantes ambientais e estética nos espaços de informação. Porto Alegre: Editora UFRGS, 2012. 